\title{
An Oral Myiasis Case Caused by Diptera (Calliphoridae) Larvae in Turkey
}

\author{
Türkiye'de Diptera (Calliphoridae) Larvalarnnın Neden Olduğu Bir Oral \\ Miyazis Olgusu
}

\author{
(1) Zeynep Taş Cengiz ${ }^{1}$, (1) Hasan Yllmaz ${ }^{1}$, (1) Yunus Emre Beyhan ${ }^{1}$, (1) Ümit Yakan², (1) Abdurrahman Ekici ${ }^{1}$ \\ ${ }^{1}$ Van Yüzüncü Yll University Faculty of Medicine, Department of Parasitology, Van, Turkey \\ ${ }^{2}$ Finike State Hospital, Clinic of Infection Diseases and Clinical Microbiology, Antalya, Turkey
}

Cite this article as: Taş Cengiz Z, Yılmaz H, Beyhan YE, Yakan Ü. An Oral Myiasis Case Caused by Diptera (Calliphoridae) Larvae in Turkey. Turkiye Parazitol Derg 2019;43(4):213-5.

\begin{abstract}
The objective of the present study is to present a patient with oral myiasis caused by Calliphoridae larvae. The patient was a 63-year-old male who was transferred from Van Closed Prison to Yüzüncü Yll University, Faculty of Medicine Research and Application Hospital. Five alive larvae localized in different points of gingival region were observed during routine oral cleaning. These larvae belonged to Calliphoridae family. As a result, medical staff should be informed about this infestation and this parasite should be kept in mind especially in risky group of patients and necessary controls should be conducted.
\end{abstract}

Keywords: Oral myiasis, diptera, Calliphoridae

\section{ÖZ}

Bu çalışmanın amacı, Calliphoridae larvalarının neden olduğu oral bir miyaz olgusunu sunmaktır. Olgu, Van Kapalı Cezaevi'nden Van Yüzünücü Yıl Üniversitesi Tıp Fakültesi Araştırma ve Uygulama Hastanesi’ne transfer edilen 63 yaşında bir erkek hastaydı. Rutin ağız temizliği sırasında farklı gingival bölgelerde lokalize olmuş beş adet canlı larva gözlendi. Bu larvaların Calliphoridae familyasına ait olduğu tespit edildi. Sonuç olarak, sağlık çalışanları bu enfestasyon hakkında bilgilendirilmeli ve özellikle riskli hasta gruplarında bu parazit düşünülerek gerekli kontroller yapılmalıdır.

Anahtar Kelimeler: Oral miyaz, diptera, Calliphoridae

\section{INTRODUCTION}

Myiasis is defined as an infestation of live humans and vertebrate animals by larvae of Diptera, which for a certain period feed on the host's dead or living tissues, body liquids, substances or ingested food (1). Based on the anatomic sites, affected myiasis is subdivided into cutaneous myiasis, myiasis of external orifices (aural, ocular, nasal, oral, vaginal and anal), and myiasis of internal organs (intestinal and urinary). Flies that cause myiasis are classified into seven different families (Calliphoridae, Sarcophagidae, Oestridae, Hypodermatidae, Gasterophilidae, Glossinidae and Muscidae) (2,3).

Oral myiasis is a condition in which soft tissues of the oral cavity are invaded by the larvae of flies (1).
Cochliomyia hominivorax, Wohlfahrtia magnifica, Musca domestica, Musca nebulo, Chrysomya bezziana, Oestrus ovis, Hypoderma bovis, Hypoderma tarandi, Gasterophilus intestinalis, and Calliphora vicina are reported in oral myasis cases in the world (4). Oral myiasis cases are caused by W. magnifica, H. bovis, Sarcophaga spp. and Calliphora spp. have been reported in Turkey (2,3,5-7).

Oral myiasis has been related to bad oral hygiene, anterior open bite, which is an orthodontic disorder, neurological deficit or psychiatric disorders and alcoholism $(8,9)$. Pain and swelling of the mouth, the teeth, the lips, or the palates and a sensation of movement are some of the reported symptoms related to oral myiasis (4).

Received/Geliş Tarihi: 07.01.2019 Accepted/Kabul Tarihi: 01.11.2019

Address for Correspondence/Yazar Adresi: Zeynep Taş Cengiz MD, Van Yüzüncü Yıl University Faculty, Department of Parasitology, Van, Turkey

E-mail/E-Posta: yebeyhan@gmail.com ORCID ID: orcid.org/0000-0002-5247-5644 
The objective of this study is to present an oral myiasis case induced by Calliphoridae larvae.

\section{CASE REPORT}

The case was a 63 years old male patient transferred from Van Closed Prison to Yüzüncü Yll University, Faculty of Medicine Research and Application Hospital. Intracerebral hemorrhage, respiratory failure and hypertension were determined in the patient at the emergency room. Following the diagnosis, the patient was transferred to anesthesiology and reanimation intensive care unit. General assessment of the patient was poor and he was unconscious. The patient who was connected to the mechanical ventilator suffered multiple organ failure. It was observed that general condition of the patient deteriorated every day. During intensive care follow-up of the patient, five alive larvae localized in different points of gingival region were observed during routine oral cleaning. These larvae were collected from the patient's mouth and oral cleaning was completed. A mild erythema was detected in gingival region of the patient. It was also observed that the patient's oral and dental hygiene was poor and these locations provided an ideal media for the larvae to settle (Figure 1). The patient died 6 days after his acceptance in the hospital.

Larvae collected from the patient's mouth were measured and found that they had a mean length of 9-10 mm. The larvae were examined under stereo microscope and posterior end lateral cross-sections were obtained to determine the larva period and taxonomic definition. These cross sections were stored in $30 \%$ potassium hydroxide until they became transparent. The diagnosis of the larvae was made by evaluating both posterior spiracle structures and other morphological features (10). It was understood that the agents were the $3^{\text {rd }}$ period larva of flies that belong to Calliphoridae family (Figure 2, 3).

\section{DISCUSSION}

Oral myiasis is observed rarely and only under certain conditions in humans. In cases reported in different countries, it was observed that fly larvae of different species caused myiasis $(2,3,9,11,12)$.

O. ovis was identified in a 5 years old child who had poor living

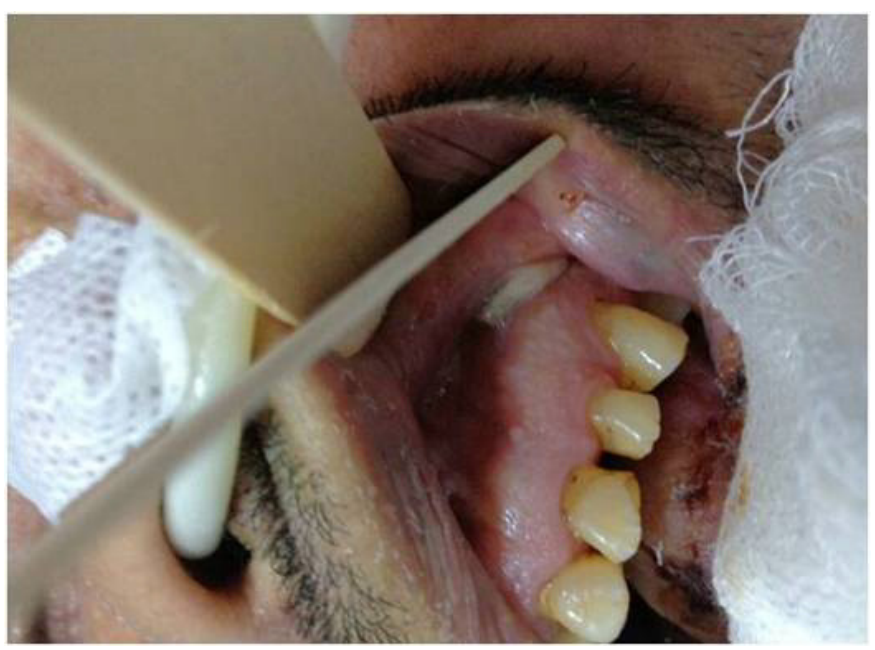

Figure 1. Larvae in the gingival region of the patient (Original) conditions and with poor oral hygiene and whose family members were ranchers in Italy (1), $M$. domestica was identified in a 45 years old male patient with a history of trauma in India (11), C. bezziana was identified in a paralyzed 89 years old female in Hong Kong (12), Lucilia sericata was identified in a 32 years old male patient who was an inpatient at an intensive care unit after surgical complications in Spain (9). Furthermore, oral myiasis was diagnosed in a 12 years old male adolescent with neurological deficit in India, however the agent species was not determined in that case (8).

In Turkey, W. magnifica was identified in a 43 years old male patient with poor oral hygiene (3); Sarcophaga spp. was identified in a 15 years old male adolescent with tuberculosis meningitis (2); H. bovis was identified in a 4 years old girl (5) and Calliphora spp. was determined in a 26 years old male farmer (6). In these cases, erythematous gingival lesion (2), edema, bleeding (6), lip swelling, mouth dryness (5), erythema and edema (3) have been detected.

In the present study, it was observed that the case had poor oral hygiene and a mild erythema (Figure 1). Furthermore, it was clear that the psychological status of the case was far from perfect under penitentiary conditions. Due to these preliminary conditions, it was understood that the presence and development of the larvae in the mouth were not recognized by the patient.

As a result, it was determined that medical staff should be informed about this infestation and consider this parasite especially in risk group patients and conduct necessary controls.

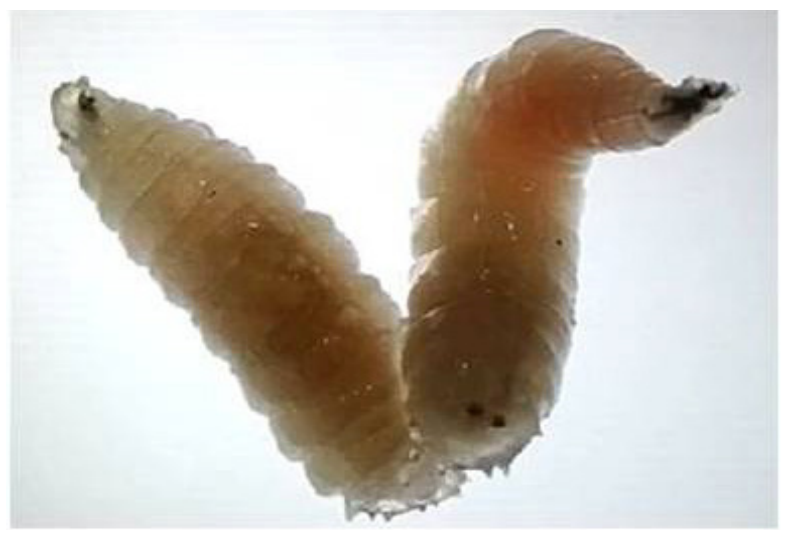

Figure 2. Calliphoridae family $3^{\text {rd }}$ period larva (Original)

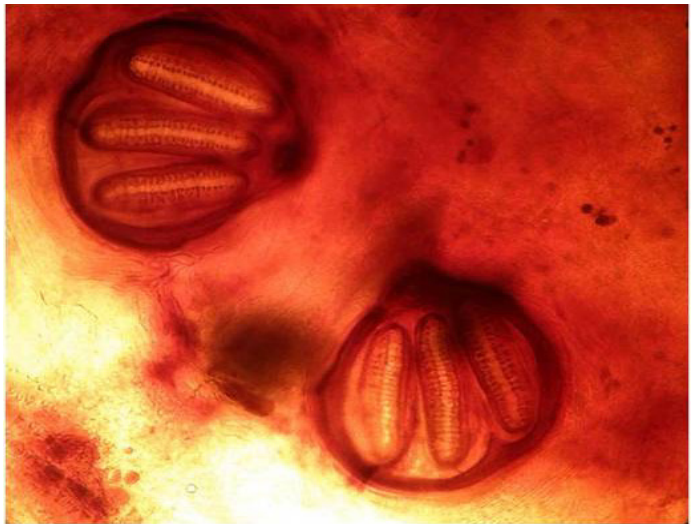

Figure 3. Posterior stigma of Calliphoridae family $3^{\text {rd }}$ period larva (Original) 


\section{${ }^{*}$ Ethics}

Informed Consent: Patient consent was not obtained.

Peer-review: Internally peer-reviewed.

\section{* Authorship Contributions}

Surgical and Medical Practices: Y.E.B., Ü.Y., Concept: Z.T.C., Y.E.B., Design: H.Y., Data Collection or Processing: Z.T.C., H.Y., A.E., Analysis or Interpretation: Z.T.C., A.E., Ü.Y., Literature Search: Z.T.C., Writing: Z.T.C., H.Y., Y.E.B.

Conflict of Interest: No conflict of interest was declared by the authors.

Financial Disclosure: The authors declared that this study received no financial support.

\section{REFERENCES}

1. Raffaldi I, Scolfaro C, Pinon M, Longo S, Savoia D, Tovo PA. A strange gingival swelling in an Italian child: a case of oral myiasis. Infez Med 2013;21:56-9.

2. Yazar S, Dik B, Yalçın Ş, Demirtaş F, Yaman O, Öztürk M, et al. Nosocomial oral myiasis by Sarcophaga sp. in Turkey. Yonsei Med J 2005;46:431-4.
3. Çetin Özdemir E, Ekşi F, Şenyurt SZ, Üstün K, Karaoğlan İ, Ercıyas K. A case of gingival myiasis caused by Wohlfahrtia magnifica. Mikrobiyol Bul 2014;48:512-7.

4. Francesconi F, Lupi O. Myiasis. Clin Microbiol Rev 2012;25:79-105.

5. Erol B, Unlü G, Balci K, Tanrikulu R. Oral myiasis caused by Hypoderma bovis larvae in a child: a case report. J Oral Sci 2000;42:247-9.

6. Gursel M, Aldemir OS, Ozgur Z, Ataoglu T. A rare case of gingival myiasis caused by Diptera (Calliphoridae). J Clin Periodontol 2002;29:777-80.

7. Özcel MA, Özbel Y, Ak M. Özcel'in Tıbbi Parazit Hastalıkları. İzmir: Meta Basim; 2007.

8. Bhola N, Jadhav A, Borle R, Adwani N, Khemka G, Jadhav P. Primary oral myiasis: a case report. Case Rep Dent 2012;2012:1-4.

9. Perez-Giraldo C, Marquez-Laffon I, Blanco MT, Munoz Del Rey JR, Chavero MJ, Habela MA, et al. A case of human oral myiasis by Lucilia sericata in a hospitalized patient in Extremadura, Spain. Case Rep Med 2012;2012:1-3.

10. Zumpt F. Myiasis in Man and Animals in the Old World. Glasgow: Butterworth \& Co (Publishers) Ltd; 1965.

11. Lata J, Kapila BK, Aggarwal P. Oral myiasis. A case report. Int J Oral Maxillofac Surg 1996;25:455-6.

12. $\mathrm{Ng} \mathrm{KH}$, Yip KT, Choi CH, Yeung KH, Auyeung TW, Tsang AC, et al. A case of oral myiasis due to Chrysomya bezziana. Hong Kong Med J 2003;9:454-6. 